\title{
Biominerals Formed by DNA and
}

\section{Calcium Oxalate or Hydroxyapatite: A}

\section{Comparative Study}

Guillem Revilla-López, ${ }^{1}$ Anna M. Rodríguez-Rivero, ${ }^{2,3}$ Luis J. del Valle, ${ }^{1,4}$ Jordi Puiggalí, ${ }^{1,4,5}$ Pau Turon $^{2, *}$ and Carlos Alemán ${ }^{1,4,5, *}$

${ }^{1}$ Departament d'Enginyeria Química, EEBE, Universitat Politècnica de Catalunya, C/Eduard Maristany 10-14, Edif. I2, 08019 Barcelona, Spain

${ }^{2}$ Research and Development, B. Braun Surgical, S.A. Ctra. de Terrassa 121, 08191 Rubí, Barcelona, Spain

${ }^{3}$ Universitat Autònoma de Barcelona. Campus de la UAB, Plaça Cívica, 08193 Bellaterra, Barcelona, Spain

${ }^{4}$ Barcelona Research Center for Multiscale Science and Engineering, EEBE, Universitat Politècnica de Catalunya, C/Eduard Maristany 10-14, Edif. C, 08019 Barcelona, Spain

${ }^{5}$ Institute for Bioengineering of Catalonia (IBEC), The Barcelona Institute of Science and Technology, Baldiri Reixac 10-12, 08028 Barcelona, Spain

*Correspondence to: pau.turon@bbraun.com and carlos.aleman@upc.edu 


\begin{abstract}
Biominerals formed by DNA and calcium oxalate $(\mathrm{CaOx})$ or hydroxyapatite (HAp; the most important and stable phase of calcium phosphate) have been examined and compared using a synergistic combination of computer simulation and experimental studies. The interest of this comparison stems from the medical observation that HApand $\mathrm{CaOx}$-based microcalcifications are frequently observed in breast cancer tissue and some of their features are used as part of the diagnosis. Molecular dynamics simulations show that: 1) the DNA double helix remains stable when it is adsorbed onto the most stable facet of HAp, whereas it undergoes significant structural distortions when it is adsorbed onto $\mathrm{CaOx}$; 2) DNA acts as template for the nucleation and growth of HAp but not for the mineralization of $\mathrm{CaOx}$; 3 ) the DNA double helix remains stable when it is encapsulated inside HAp nanopores but it becomes destabilized when the encapsulation occurs into $\mathrm{CaOx}$ nanopores. Furthermore, $\mathrm{CaOx}$ and $\mathrm{HAp}$ minerals containing DNA molecules inside and/or adsorbed on the surface have been prepared in the lab by mixing solutions containing the corresponding ions with fish sperm DNA. Characterization of the formed minerals, which has been focused on the identification of DNA using UV-vis spectroscopy, indicates that the tendency to adsorb and, especially, encapsulate DNA is much smaller for $\mathrm{CaOx}$ than for $\mathrm{HAp}$, which is in perfect agreement with results from MD simulations. Finally, quantum mechanical calculations have been performed to rationalize these results in terms of molecular interactions, results evidencing the high affinity of $\mathrm{Ca}^{2+}$ towards oxalate anions in aqueous environment.
\end{abstract}




\section{INTRODUCTION}

The combination of DNA with nanomaterials (e.g. gold and metal oxide nanoparticles, carbon-based nanomaterials and minerals) to form hybrid systems is of fundamental interest for applications in DNA delivery, biosensors development and nanotechnology. ${ }^{1-8}$ Within this extensive field of research, the interaction of DNA with nanostructured calcium phosphate $(\mathrm{CaP})$ is especially relevant because of its important biological implications. In particular, hydroxyapatite (HAp), which is probably the most important phase of $\mathrm{CaP}$, is the main mineral of mammalian tooth enamel and bone, ${ }^{9}$ where it grows as nano-sized mineral platelets at nucleating sites on a protein template. ${ }^{10,11}$ Understanding the interaction between HAp and DNA has been found to be essential for biomedical field applications. For example, HAp nanoparticles (NPs) have been used for cell transfection as carrier of nucleic acids ${ }^{12-15}$ and for purifying DNA from virus. ${ }^{16}$

On the other hand, spectroscopic studies on HAp microcalcifications formed inside living organism (i.e. tumoral tissue) showed the contribution of vibrational modes of DNA, phospholipids and proteins. ${ }^{17}$ Such finding is particularly relevant since HAp detection in breast cancer microcalcifications have been successfully used for screening and diagnosis purposes. ${ }^{18-20}$ More specifically, such analyses concentrated on the chemical differentiation between two minerals: calcium oxalate $(\mathrm{CaOx})$, usually associated with benign prognosis, and HAp, which is more frequently associated with malignancy. ${ }^{21,22}$

In recent years the interaction between plasmid DNA and both nanostructured HAp, $\mathrm{Ca}_{10}\left(\mathrm{PO}_{4}\right)_{6}(\mathrm{OH})_{2}$, and amorphous $\mathrm{CaP}$ has been examined. ${ }^{23-28}$ Results showed that DNA adsorption depends on the HAp morphology, NPs and fusiform nanorods adsorbing more DNA than flower-like and laminar nanocrystals. ${ }^{23}$ Similar results were 
obtained for polyphosphates, which mimicked the backbone of DNA. ${ }^{24}$ Structural changes induced in plasma DNA by the adsorption on HAp resulted in an enhanced stabilization, increasing the resistance against enzymatic digestion. ${ }^{23}$ Besides, the formation of HAp was found to be regulated by DNA, which acts as a template in a "biomineralization" process. ${ }^{25-28}$ More specifically, the DNA backbone behaved as a very large nucleus for the growth of HAp surrounding the biomolecule. ${ }^{28}$ Moreover, the utilization of HAp NPs as non-viral vectors for transfection has been demonstrated, proving that such inorganic particles are able to deliver DNA or RNA to a cell. ${ }^{23,29-31}$ Interestingly, $\mathrm{Mg}^{2+}$ was found to play a unique role in the DNA-HAp biomineralization process since this ion has a very high affinity towards DNA, whereas in the initial stages of the particle nucleation process it prefers to be located at the surface regions rather than at the core ones. ${ }^{32}$

This work renders a physical-chemical explanation to a long term debate in the medical community regarding if and why breast cancer patients with HAp-based microcalcifications have a worse prognosis compared to those showing mostly $\mathrm{CaOx}$-based micro-calcifications. The first part of the paper deals with the energetics and statistical mechanics of mineral $\cdots$ DNA complexation and the second part proves that DNA can only be encapsulated without denaturalization in HAp-based matrices thus forming biominerals not only able to encapsulate and transport DNA but also to deliver it. ${ }^{33}$ For this purpose, we have used a synergistic approach to compare DNA mineralization in HAp and $\mathrm{CaOx}$. Particularly, the capacity of DNA to interact with HAp and $\mathrm{CaOx}$ has been examined theoretically and experimentally. Initially, molecular dynamics (MD) simulations have been carried out in order to analyze: the adsorption of DNA onto the most stable facet of HAp and $\mathrm{CaOx}$, the growing of HAp and $\mathrm{CaOx}$ minerals around the DNA template (i.e. the nucleating effect of DNA), and the stability of biominerals 
formed by DNA encapsulated inside nanopores of HAp or CaOx. After this, DNA$\mathrm{CaOx}$ and DNA-HAp complexes have been synthesized in the laboratory and studied by $\mathrm{UV}$-vis spectroscopy to compare the ability of these minerals to adsorb and encapsulate DNA. Finally, quantum mechanical (QM) calculations have been conducted to provide a comprehensive chemical explanation of the results derived from both MD simulations and UV-vis spectroscopy, which are fully consistent. It is worth mentioning that special attention has been given to the discussion of the biominerals involving $\mathrm{CaOx}$, which have been much less studied than those that contain HAp, and to the role of $\mathrm{Mg}^{2+}$.

\section{METHODS}

\section{Molecular dynamics}

MD simulations were performed with the NAMD 2.6 software package. ${ }^{34}$ In order to study the adsorption and encapsulation of DNA in CaOx and HAp, we took into consideration the clinical interest of hypomethylated and hypermethylated DNA sequences as they have been associated with the overexpression of genes or genes silenced linked to cancer disease. ${ }^{35-38}$ More specifically, two representative DNA dodecamers were selected to cover the full range of methylation: a) the highly methylated dodecamer 5' $-\mathrm{CG}^{4} \mathrm{GTCG}^{5} \mathrm{CCG}^{6} \mathrm{TCG}^{7}-3^{\prime}$ ' (hereafter R1A) extracted from the RASSF1A gene; and b) the Dickerson dodecamer 5'-CGCGAATTCGCG-3' (hereafter DD) as representative of unmethylated sequences. The DD is widely used as DNA probe in experiments, working as a wildcard when no specific sequence is investigated. On the other hand, hypermethylation of the RASSF1A gene has been correlated with clinical and pathological characteristics of breast cancer and with clinical outcomes. ${ }^{39}$ Charge neutralization was performed with the addition of $\mathrm{Mg}^{2+}$ counterions, which were located at the major groove of the double helix. ${ }^{40}$ 
Force-field parameters for DNA and phosphate anions were taken from ff99-SB, ${ }^{41}$ $\mathrm{Ca}^{2+}$ parameters were from Bradbook et al. $^{42}$ and parameters for $\mathrm{Mg}^{2+}$ were from Sorensen et $a l .{ }^{43}$ The TIP3P $\mathrm{P}^{44}$ water model was employed to describe explicit water molecules. In previous work we used quantum mechanical calculations on model systems to demonstrate that such combination of force-field parameters satisfactorily reproduce the interactions of DNA $\cdots$ HAp systems. ${ }^{25}$ Bonding and van der Waals parameters for oxalate anions $\left(\mathrm{Ox}^{2-}\right)$ were extracted from the general Amber force-field gaff, ${ }^{45}$ while charges were developed following the $\operatorname{RESP}^{46}$ protocol and using ab initio $\mathrm{HF} / 6-31 \mathrm{G}^{*}$ calculations.

All productive MD runs were performed in the NPT ensemble at $298 \mathrm{~K}$ and 1 bar. Both temperature and pressure were controlled by the Berendsen thermobarostat. ${ }^{47}$ Productive MD simulations were conducted using an integration time step of $2 \mathrm{fs}$. Representative structures were extracted every 500 steps. Van der Waals interactions were evaluated with a cut-off of $10 \AA$ and a switching distance at $8 \AA$. For electrostatic interactions, we computed the non-truncated electrostatic potential throughout Ewald Summations, i.e. the Particle-Mesh Ewald (PME) method. ${ }^{48}$ The real space term was determined by the van der Waals cut-off $(10 \AA)$, while the reciprocal term was estimated by interpolation of the effective charge into a charge mesh with a grid thickness of 5 points per volume unit. In all cases bond lengths involving hydrogen were kept frozen by using the SHAKE algorithm. ${ }^{49}$

Adsorption of DNA. The HAp hexagonal unit cell with $P 6_{3} / m$ geometry $(a=b=9.421$ $\AA, c=6.881 \AA, \alpha=\beta=90^{\circ}$, and $\gamma=120^{\circ}$ ) and the $4 \mathrm{e}$ Wyckoff position occupied by two hydroxyl ions, each with $1 / 2$ occupancy, ${ }^{50}$ and the monohydrated $\mathrm{CaOx}$ monoclinic unit cell with $P 2_{1} / c$ geometry $\left(a=6.316 \AA, b=14.541 \AA, c=10.116 \AA, \alpha=\gamma=90^{\circ}\right.$, and $\beta=$ $\left.109^{\circ}\right)^{51}$ were generated. These systems were cleaved to obtain the most stable facet of 
such minerals (see below). HAp and $\mathrm{CaOx}$ unit cells were expanded 6 and 4 times in the $x$ and $y$ directions, respectively, creating $6 \times 6$ and $4 \times 4$ supercells. The thickness of the supercell in the $z$ axis entailed a 4 and 2 layer slab for HAp and $\mathrm{CaOx}$, respectively. Afterwards, both surfaces were solvated in the $z$ direction with 17756 and 12532 water molecules for the (001) of HAp and the (100) of $\mathrm{CaOx}$, respectively.

Initially, water and DNA coordinates were optimized through 5000 steps of conjugated gradient algorithm minimization. The resulting coordinates of the two systems underwent $0.5 \mathrm{~ns}$ of NVT molecular dynamics (MD) at $373 \mathrm{~K}$ with frozen coordinates for the DNA and the mineral. Final coordinates and velocities of the NVT run were used as input for $0.5 \mathrm{~ns}$ NPT ( $298 \mathrm{~K}, 1$ bar) to equilibrate energy and water density (to $1 \mathrm{~g} / \mathrm{cm}^{3}$ ) in the volume occupied by the liquid and the DNA. The Berendsen thermobarostat ${ }^{47}$ was employed at constant $x y$ plane area and frozen DNA and mineral slab coordinates. Productive dynamics started from the latter output, only keeping fixed the mineral atoms. Trajectories were $150 \mathrm{~ns}$ long.

DNA in solution. The R1A and DD double helices and $\mathrm{Mg}^{2+}$ counterions were solvated with 30000 water molecules and the density of the resulting system was equilibrated to $1 \mathrm{~g} / \mathrm{cm}^{3}$ following the same protocol used for the surface slabs in the adsorption simulations. Productive control dynamics were $150 \mathrm{~ns}$ long.

Nucleation of DNA biominerals. As DNA methylation is not expected to play any role in the nucleation of biominerals, simulations were conducted using the R1A dodecamer only. The nucleation of $\mathrm{CaOx}$ around $\mathrm{R} 1 \mathrm{~A}$ was simulated considering, in addition of the dodecamer, $10 \mathrm{Mg}^{2+}, 20 \mathrm{Ca}^{2+}, 20 \mathrm{Ox}^{2-}$ molecules and 50551 water molecules. The nucleation of HAp around the R1A was examined considering a system with $10 \mathrm{Mg}^{2+}, 30 \mathrm{Ca}^{2+}, 20 \mathrm{PO}_{4}{ }^{3-}$ molecules and 51675 water molecules. 
Systems were previously equilibrated at the target temperature (298 K), pressure (1 atm) and density $\left(1 \mathrm{~g} / \mathrm{cm}^{-1}\right)$. For this purpose, 5000 steps of energy minimization were initially performed to relax structural tensions. After this, solvent and ions were thermally relaxed by three consecutive runs, while the B-DNA was kept frozen: $0.5 \mathrm{~ns}$ of NVT-MD (volume conserved) at $500 \mathrm{~K}$ were used to homogeneously distribute the solvent and ions in the box. Then, $0.5 \mathrm{~ns}$ of isothermal $(298 \mathrm{~K})$ and $0.5 \mathrm{~ns}$ of isobaric (1 atm and $298 \mathrm{~K}$ ) relaxations were run. Finally, all the atoms of the systems were submitted to $0.15 \mathrm{~ns}$ of steady heating until the target temperature was reached (298 K), $0.25 \mathrm{~ns}$ of NVT-MD at $298 \mathrm{~K}$ (thermal equilibration), followed by $0.5 \mathrm{~ns}$ of density relaxation (NPT-MD). After equilibration, productive MD simulations of $150 \mathrm{~ns}$ were conducted.

Encapsulation of DNA. The HAp hexagonal unit cell ${ }^{50}$ and the monohydrated $\mathrm{CaOx}$ monoclinic unit cell ${ }^{51}$ were used to construct super-cells considering $6 \times 6 \times 7$ and $4 \times 4 \times 5$ unit cells, respectively. After this, a hole was generated in the centre of each super-cell, the dimensions of such hole being defined by DNA double helix. After several trials, we found that a hole of $2 \times 2 \times 7$ units cells was the minimum required for both minerals to accommodate the double helix without severe steric contacts. In order to completely avoid unfavorable steric interactions between the apatite and the biomolecule, some additional atoms and groups of atoms were translated at their border regions allowing us to maintain the electroneutrality of the super-cells. Then, R1A and DD double helices, which were arranged in the canonical B form, were embedded inside the pores. In order to maintain the electrical neutrality of the system, $\mathrm{Mg}^{2+}$ ions were put at the major groove of the double helix. Figure 1 depicts the starting models used to represent DD double helix embedded into $\mathrm{HAp}$ and $\mathrm{CaOx}$ pores, starting models for the R1A sequence being analogous to these ones. 
In order to evaluate the stability of the encapsulated DNA models, both energy minimization and MD simulations were applied. Initially, all the models were minimized by applying $5 \times 10^{3}$ steps of steepest descent to relax the more important conformational and structural tensions. Then, a MD run of $3.0 \mathrm{~ns}$ in the NVT ensemble (constant number of particles, volume and temperature) at $298 \mathrm{~K}$ was carried out to equilibrate the four systems under study (i.e. R1A and DD encapsulated into HAp and $\mathrm{CaOx})$ and eliminate small structural tensions. After such thermal relaxation, the saved coordinates were submitted to a new energy minimization by applying $5 \times 10^{3}$ steps of steepest descent until energy convergence. In both energy minimizations and MD simulation, atoms contained in R1A and DD were only allowed to move from their positions, the coordinates of the mineral being kept fixed at their crystallographic positions in all cases. Each system was calculated in triplicate considering starting points that differ in the orientation of the DNA inside the generated holes.

\section{In vitro synthesis of biominerals}

In vitro synthesis of DNA-CaOx and DNA-MgOx complexes. The synchronized dropwise (rate of $2 \mathrm{~mL} / \mathrm{min}$ ) addition of $10 \mathrm{~mL}$ of a solution of $0.04 \mathrm{M}$ sodium oxalate (Sigma Aldrich 99,5\%, 223433) and $10 \mathrm{~mL}$ of $0.04 \mathrm{M} \mathrm{CaCl}_{2}$ (Scharlab, CA01920500) to $0.06 \mathrm{~g}$ of fish sperm DNA (Sigma Aldrich, 74782) was conducted under stirring at 75 ${ }^{\circ} \mathrm{C}$ for $5 \mathrm{~h}$. Then, the resulting solutions were cooled to room temperature, centrifuged and washed successively with molecular biology grade water (Millipore, H2OMB0506) twice and a 60/40 v/v mixture of ethanol-water (Ethanol, Scharlab ET0011000). A white powder with traces of pale orange was obtained after freeze-drying. Calcium chloride was replaced by $\mathrm{MgCl}_{2}$ (Sigma Aldrich, M8266), to obtain the DNA-MgOx system. 
In vitro synthesis of DNA-HAp complexes. $0.1 \mathrm{~g}$ of fish sperm DNA were added to 15 $\mathrm{mL}$ of a $0.3 \mathrm{M}\left(\mathrm{NH}_{4}\right)_{2} \mathrm{HPO}_{4}$ solution in de-ionized water. The $\mathrm{pH}$ of such solution was previously adjusted to 10 with aqueous ammonia. The mixture was added drop-wise (rate of $2 \mathrm{~mL} / \mathrm{min}$ ) and under agitation $\left(400 \mathrm{rpm}\right.$ ) to $25 \mathrm{~mL}$ of $0.3 \mathrm{M} \mathrm{Ca}\left(\mathrm{NO}_{3}\right)_{2}$ solution in de-ionized water and the appropriate amount of aqueous ammonia to adjust $\mathrm{pH}$ to 10 . Temperature was maintained at $40{ }^{\circ} \mathrm{C}$ during the addition process. After that, the reaction mixture was stirred at $80{ }^{\circ} \mathrm{C}$ for $1.5 \mathrm{~h}$ and then naturally cooled to room temperature. The resultant suspension was aged for $24 \mathrm{~h}$ at room temperature. Then, the precipitate was separated by centrifugation and washed sequentially with de-ionized water and a 60/40 v/v mixture of ethanol-water (twice). A white powder was obtained after freeze-drying.

A UV-3600 (Shimadzu) UV-Vis-NIR spectrophotometer controlled by the UVProbe 2.31 software was used to record UV-Vis spectra of DNA-CaOx, DNA-MgOx and DNA-HAp complexes at room temperature, in the 200-400 $\mathrm{nm}$ range, with a bandwidth of $0.2 \mathrm{~nm}$ and a scan speed of $600 \mathrm{~nm} / \mathrm{min}$.

\section{QM calculations}

QM calculations were performed using Gaussian 09 software package. ${ }^{52}$ Geometry optimization, solvation and binding energy calculations were carried out with the hybrid functional B3LYP ${ }^{53,54}$ combined with the 6-311G++(2d,2p) basis set. All geometry optimizations were carried out until a stationary point was reached. These were confirmed as minima by frequency analyses (i.e. no imaginary frequency was found). The gas-phase free energies were obtained at $298 \mathrm{~K}$ by correcting the energies with the zero point energy and the thermal correction term and by evaluating the entropy using standard statistical thermodynamic methods. The SMD solvation method ${ }^{55}$ was chosen 
to calculate the hydration free energy of the systems, $\Delta \mathrm{G}_{\mathrm{hyd}}$, which was estimated as the difference between the free energies in the gas-phase and aqueous solution. Binding energies, $\Delta \mathrm{G}_{\mathrm{b}}$, were calculated as $\Delta \mathrm{G}_{\mathrm{b}}=\mathrm{G}_{\mathrm{sol}, \mathrm{c}}-\Sigma_{\mathrm{i}} \mathrm{G}_{\mathrm{sol}, \mathrm{i}}$ where $\mathrm{G}_{\mathrm{sol}, \mathrm{c}}$ is the free energy of the complex in aqueous solution and $\mathrm{G}_{\mathrm{sol}, \mathrm{i}}$ is the free energy of each component of the complex in aqueous solution (i.e. $i$ stands for each of the interacting component of the complex). All $\Delta \mathrm{G}_{\mathrm{b}}$ values were corrected by the Base Superposition Error (BSSE) using the standard counterpoise protocol.

\section{RESULTS AND DISCUSSION}

\section{Adsorption of DNA on the minerals surface}

Initially, MD simulations were focused on the adsorption of R1A and DD sequences on the surface of the HAp and monohydrated $\mathrm{CaOx}$ minerals. We focused on the interaction formed when such dodecamers are adsorbed onto the most stable facet of $\mathrm{HAp}^{56}$ and monohydrated $\mathrm{CaOx},{ }^{57}$ which is the (001) and (100), respectively. AlmoraBarrios et al. ${ }^{58}$ reported that the calculated surface energies of the (001) and the average (010) surfaces are 1.01 and $1.32 \mathrm{~J} / \mathrm{m}$, respectively, indicating that the former is more stable than the latter, in agreement with previous literature. ${ }^{59,60}$ Indeed, the less stable (010) surface, which was proposed to be much less populated than the (100), quickly accumulating more material that grow out of the crystal morphology because of the reactivity associated to such instability. Besides, the (100) was identified by atomic force microscopy experiments not only as the most populated facet of $\mathrm{CaOx}^{61,62}$ but also as the surface that forms the strongest interactions with carboxylate and amidinium groups, which are abundantly present in biomolecules, including DNA. ${ }^{62}$

Although the methylated and non-methylated sequences showed a similar behaviour when interacting separately with $\mathrm{HAp}$ or monohydrated $\mathrm{CaOx}$, simulations 
demonstrated that the structural stability of DNA is totally different for each mineral. The stability of the adsorbed sequences was evaluated by examining the temporal evolution of the root mean square deviation (RMSD), which was calculated between each atom position of the B-DNA canonical double helix and the dodecamer structures recorded from MD trajectories. As shown below, the RMSD was converged for all systems preserving the B-DNA structure, whereas the RMSD was high enough to guarantee complete de-structuration for all systems in which the double helix is lost. However, in the latter cases convergence of the RMSD was not considered a requisite since the dynamics and structure of unfolded B-DNA is out of the scope of this work.

Figures $2 \mathrm{a}$ and $2 \mathrm{~b}$, which include the results obtained in aqueous solution (control), compare the RMSDs obtained for R1A and DD, respectively. The average RMSD obtained for R1A and DD adsorbed onto the (001) HAp (3.5 $\pm 0.6 \AA$ and $3.4 \pm 0.4 \AA$, respectively) is close to that obtained for the same sequence in aqueous solution (2.7 $\pm 0.5 \AA$ and $2.7 \pm 0.4 \AA$, respectively), evidencing that the B-DNA double helix remains stable when adsorbed onto HAp. Thus, the double helix is able to accommodate itself onto the HAp surface, independently of the methylation, by establishing a balance between the attractive and repulsive interactions between the phosphate groups of DNA and the $\mathrm{Ca}^{2+}$ and $\mathrm{PO}_{4}{ }^{3-}$ ions of the mineral, respectively. The formation of such interactions is reflected in Figures $2 \mathrm{c}$ and $\mathrm{S} 1 \mathrm{a}$ for R1A and DD, respectively, which display a representative snapshot of the dodecamer adsorbed onto HAp and compares the adsorbed double helix with a canonical one. The affinity of HAp towards the double helix of DNA has been attributed to the complementarity between the mineral and the phosphate groups of the DNA backbone, which were found to exhibit isomorphic planes. $^{25}$ 
In contrast, the average RMSD increases progressively for the R1A and DD sequences adsorbed on the (100) facet of monohydrated $\mathrm{CaOx}$, reaching in both cases values higher than $8 \AA$ after 150 ns. Thus, the $\mathrm{CaOx}$ surface causes a drastic destabilization of the adsorbed double helix due to the electrostatic repulsions between the $\mathrm{Ox}^{2-}$ and polyphosphate DNA backbone, which are directly confronted. The effect of $\mathrm{Ox}^{2-} \ldots$ polyphosphate repulsive interactions in the double helix is illustrated in Figures $2 \mathrm{~d}$ and $\mathrm{S} 1 \mathrm{~b}$ for $\mathrm{R} 1 \mathrm{~A}$ and $\mathrm{DD}$, respectively. As it can be seen, electrostatic repulsions tend to deploy the DNA double helix, separating the two strands. This destabilizing effect is not offset by the water molecules of the internal monohydration layer, which practically does not interact with the superficial DNA.

\section{Nucleation of DNA templated biominerals}

The behavior of R1A in an ionic solution to assess the feasibility of DNA to nucleate $\mathrm{CaOx}$ and/or HAp biominerals and act as a template was modelled using solution-like systems containing $\mathrm{Ox}^{2-}$ or $\mathrm{PO}_{4}{ }^{3-}$ ions together with the DNA dodecamer, $\mathrm{Ca}^{2+}$ and $\mathrm{Mg}^{2+}$. Figure 3a shows the radial distribution functions (RDFs) derived from the simulation with $\mathrm{Ox}^{2-}$ for the following pairs: $\mathrm{Mg}^{2+}-\mathrm{DNA} p$ (where DNA $p$ refers to the centre of masses of the phosphate groups from the DNA backbone), $\mathrm{Ca}^{2+}-\mathrm{DNA} p$, $\mathrm{Mg}^{2+}-\mathrm{Ox}^{2-}$ (where $\mathrm{Ox}^{2-}$ refers to the centre of masses of $\mathrm{Ox}^{2-}$ anions), $\mathrm{Ca}^{2+}-\mathrm{Ox}^{2-}$ and DNA $p-\mathrm{Ox}^{2-}$. For a given pair, $\alpha-\beta$, the RDF curve gives a measure of the relative probability that $\beta$ resides at a radial distance $r$ from $\alpha$ centred at the origin of coordinates.

The profile obtained for $\mathrm{Mg}^{2+}-\mathrm{DNA} p$ pair (black) shows a sharp peak at $r=1.9$ $\AA$, evidencing the high affinity of $\mathrm{Mg}^{2+}$ towards DNA. Besides, the first peak for the $\mathrm{Ca}^{2+}-\mathrm{DNA} p$ pair, which appears at $r=2.6 \AA$, apparently displays a lower area 
under the curve (red). On the other hand, the area under the $\mathrm{Ca}^{2+}-\mathrm{Ox}^{2}$ peak at $r=$ $2.6 \AA$ (light blue) is much higher, reflecting that the attraction of $\mathrm{Ca}^{2+}$ by the $\mathrm{Ox}^{2-}$ is very favoured in comparison to the affinity by the phosphate groups from DNA. Interestingly, $\mathrm{Ox}^{2-}$ anions do not exhibit any affinity towards DNA, an equi-probable distribution being found once an exclusion threshold at $r=5.5 \AA$ is exceeded.

Considering the possibility of forming triads like DNA $p \cdots \mathrm{X} \cdots \mathrm{Ox}{ }^{2-}$, where $\mathrm{X}$ refers to $\mathrm{Ca}^{2+}$ or $\mathrm{Mg}^{2+}$ coordination ions, analysis of the RDFs shows that $\mathrm{Ca}^{2+}$ cannot play this role. Once $\mathrm{Ca}^{2+}$ is bound to DNAp or to $\mathrm{Ox}^{2-}$ prefers the interaction with surrounding explicit water molecules instead of forming the triad. Thus, the sum of the $r$ values for the first peak of the $\mathrm{Ca}^{2+}-\mathrm{DNA} p$ and $\mathrm{Ca}^{2+}-\mathrm{Ox}^{2-} \mathrm{RDF}$ totals $5.2 \AA$, this value being lower than the threshold distance of cation-mediated DNAp-Ox ${ }^{2-}$ carboxyl interaction (i.e. $5.5 \AA$ ). The addition of the distances associated to the first peak of $\mathrm{Mg}^{2+}-\mathrm{DNA} p$ and $\mathrm{Mg}^{2+}-\mathrm{Ox}^{2-}$ RDFs renders a value of $6.0 \AA$, which is bigger than the cation mediated threshold. However, the absence of peaks in the RDF of the DNAp-Ox ${ }^{2-}$ pair suggests that DNA $p \cdots \mathrm{Mg}^{2+} \cdots \mathrm{Ox}^{2-}$ interactions are extremely weak in highly hydrated environments. The above mentioned tendencies are reflected in Figure 3b, which displays a snapshot from the MD simulation of the modelled system (red box). As it can be seen, $\mathrm{Ox}^{2-}$ anions tend to form clusters with $\mathrm{Ca}^{2+}$ cations separated from the DNA. Apparently, the polyphosphate groups from DNA do not play any significant role in the formation of $\mathrm{CaOx}$.

Figure $3 c$ displays the RDFs derived from the simulation with $\mathrm{PO}_{4}{ }^{3-}$ for the $\mathrm{Mg}^{2+}-$ DNAp, $\mathrm{Ca}^{2+}-\mathrm{DNA} p, \mathrm{Mg}^{2+}-\mathrm{PO}_{4}{ }^{3-}$ (where $\mathrm{PO}_{4}{ }^{3-}$ refers to the centre of masses of $\mathrm{PO}_{4}{ }^{3-}$ anions), $\mathrm{Ca}^{2+}-\mathrm{PO}_{4}{ }^{3-}$ and DNAp- $\mathrm{PO}_{4}{ }^{3-}$ pairs. The profiles obtained for $\mathrm{Mg}^{2+}-\mathrm{DNA} p$ and 
$\mathrm{Ca}^{2+}-\mathrm{DNA} p$ pairs (black and red, respectively) show sharp peak at $r=1.9$ and $2.5 \AA$, respectively. Thus, although the affinity of the DNA dodecamer towards $\mathrm{Mg}^{2+}$ is higher than towards $\mathrm{Ca}^{2+}$, the latter ion interacts more with the phosphate groups of DNA than in the simulation with $\mathrm{Ox}^{2-}$. Besides, the $\mathrm{Ca}^{2+}-\mathrm{PO}_{4}{ }^{3-}$ profile shows a sharp peak at $r=$ $2.5 \AA$ (light blue), indicating that the attraction of $\mathrm{Ca}^{2+}$ by $\mathrm{PO}_{4}{ }^{3-}$ anions and DNAp is very similar. However, the most important difference between simulations with $\mathrm{Ox}^{2-}$ and $\mathrm{PO}_{4}{ }^{3-}$ is detected in the RDF calculated for the DNA $p-\mathrm{PO}_{4}{ }^{3-}$ pair (green), which shows a broad peak centered at $r=5.00 \AA$. This peak evidences that $\mathrm{PO}_{4}{ }^{3-}$ anions tend to be distributed around the DNA, which acts as a template and facilitates the growing of the mineral around it.

Moreover, in this case the formation of both DNAp $\cdots \mathrm{Ca}^{2+} \cdots \mathrm{PO}_{4}{ }^{3-}$ and DNA $p \cdots \mathrm{Mg}^{2+} \ldots \mathrm{PO}_{4}{ }^{3-}$ triads is consistent with the peaks observed in the RDFs. Thus, the addition of the $r$ values for the first peak of the $\mathrm{Ca}^{2+}-\mathrm{DNA} p$ and $\mathrm{Ca}^{2+}-$ $\mathrm{PO}_{4}{ }^{3-} \mathrm{RDFs}$ sums $5.0 \AA$, which matches the maximum of the broad peak obtained for the DNA $p-\mathrm{PO}_{4}{ }^{3-} \mathrm{RDF}$ (i.e. 5.0 $\AA$ ). Besides, the sum of the distances associated to the first peak of $\mathrm{Mg}^{2+}-\mathrm{DNA} p$ and $\mathrm{Mg}^{2+}-\mathrm{PO}_{4}{ }^{3-}$ is $4.3 \AA$, which is within the area of the broad peak obtained for DNAp- $\mathrm{PO}_{4}{ }^{3-}$. These results indicate that $\mathrm{PO}_{4}{ }^{3-}$ anions tend to form clusters around the polyphosphate backbone of DNA, repulsive interactions being shielded by the $\mathrm{Ca}^{2+}$ and $\mathrm{Mg}^{2+}$ ions located between them. This clustering distribution is shown in Figure 3b, which displays a representative snapshot from the MD simulation of the $\mathrm{PO}_{4}{ }^{3-}$ containing system (blue ellipsoid) superposed to that from simulation with $\mathrm{Ox}^{2-}$. Overall, the formation of calcium phosphate clusters surrounding the DNA backbone is fully consistent with previous experimental observation, in which the 
DNA was found to act as template for the nucleation and growth of crystalline HAp. $^{28}$

\section{Encapsulation of DNA inside mineral nanopores}

In order to elucidate DNA can be present inside HAp and $\mathrm{CaOx}$ in microcalcifications, the encapsulation of R1A and DD in mineral nanopores was modelled. Figure 4 represents the structure of R1A and DD dodecamers embedded in $\mathrm{HAp}$ and $\mathrm{CaOx}$ nanopores after relaxation through energy minimizations and $\mathrm{MD}$, as is described in the Methods section.

In the case of HAp, the DNA double helix occupies practically the whole pore, independently of its methylation degree. Although interactions with mineral ions induce some distortions in the backbone, the DD and R1A double helix with its intra-strand stacking and the inter-strand hydrogen bonds are clearly preserved. This is illustrated in Figure 4, which also depicts the double helix without the mineral. As it can be seen, initial double helices do not undergo significant distortions, which is fully consistent with the simulations discussed in the previous sub-section. Thus, the attractive interaction between the $\mathrm{Ca}^{2+}$ ions of HAp and the polyphosphate chain of the DNA allows maintaining the stability of the B-DNA inside the pore. The RMSD between the canonical double helix (i.e. the starting structure) and the relaxed double helix, which was calculated considering all the atoms, is relatively small: 1.9 and $3.5 \AA$ for R1A and $\mathrm{DD}$, respectively.

Relaxation of R1A and DD dodecamers embedded in $\mathrm{CaOx}$ induced drastic geometric distortions that affected significantly both the inter-strand hydrogen bonds and the intra-strand $\pi-\pi$ stacking, as is displayed in Figure 4. Thus, the RMSD calculated with respect to the canonical B-DNA used as starting point was close to $10 \AA$ 
for both sequences, which is significantly higher than the values obtained for complexes with HAp. This is because of the repulsive interactions between the $\mathrm{Ox}^{2-}$ anions and the phosphate groups of the double helix that, in this case, are not shielded by the attractive interactions of the latter with the $\mathrm{Ca}^{2+}$ ions. Apparently, these results indicate that the geometry of $\mathrm{CaOx}$ is not appropriated to preserve the tertiary structure of the biological DNA when the latter is embedded inside of the nanopore.

Overall, these results indicate that the cavity generated in HAp allows B-DNA double helices encapsulation without producing mineral-induced stress, while the opposite situation is obtained when $\mathrm{CaOx}$ nanopores are studied. Although this feature might be related with the benign and malignancy cancer prognosis associated to $\mathrm{CaOx}$ and HAp microcalcifications, ${ }^{21-22}$ no experimental observation relating the medical diagnosis and the functionality of the genes linked to cancer disease has been reported yet.

\section{Experimental DNA mineralization}

As a consequence of the previous in silico results, DNA mineralization with $\mathrm{CaOx}$, magnesium oxalate $(\mathrm{MgOx})$ and HAp was investigated forming DNA-CaOx, DNAMgOx and DNA-HAp complexes through the procedure described in the Methods section. It is worth noting that DNA was incorporated into aqueous inorganic solutions and, therefore, the biomolecule could be absorbed onto the surface of the formed mineral particles or encapsulated into them. The non-physiological conditions used in these experiments have been used as a proof of concept for the underlying physicochemical mechanism considering monohydrated $\mathrm{CaOx}$ and $\mathrm{HAp}$, which are the

minerals employed in the simulations. Thus, the conditions used for the in vitro synthesis of minerals have avoided mixed effects of other crystalline forms, as for 
example dihydrated and trihydrated in the case of $\mathrm{CaOx}$ and brushite, tricalcium phosphate or amorphous calcium phosphate in the case of HAp

Figure 5a compares the UV-vis spectra recorded for: a1) as obtained DNA-CaOx samples; a2) digested DNA-CaOx samples, in which superficially adsorbed DNA is removed by digesting as obtained DNA-CaOx complexes with DNAase; a3) as obtained DNA-CaOx samples from a1 are re-dissolved with sodium citrate $(5 \mathrm{mM})$; and a4) digested DNA-CaOx samples dissolved with sodium citrate $(5 \mathrm{mM})$. The UV-vis spectrum of as prepared DNA-CaOx complexes (a1) clearly demonstrates the presence of DNA since a characteristic absorption peak is observed at $266 \mathrm{~nm}$. However, the absorbance at $266 \mathrm{~nm}$ decreases considerably after enzymatic degradation treatment (a2). This absorbance increases after dissolution of the as obtained DNA-CaOx complexes (a3), while it remains very small when the digested samples are dissolved (a4). Overall, these results unambiguously demonstrate that the mineralization of DNA from $\mathrm{Ca}^{2+}$ - and $\mathrm{Ox}^{2-}$-containing solutions mainly occurs through the adsorption of the biomolecule on the surface of the formed $\mathrm{CaOx}$ particles, whereas the encapsulation of DNA inside such inorganic particles is very limited.

Trying to promote the affinity of $\mathrm{Ox}^{2-}$ towards DNA, DNA-MgOx complexes were prepared following the procedure previously used to obtain DNA-CaOx complexes (see Methods section). As the electrostatic binding of $\mathrm{Mg}^{2+}$ in the grooves of DNA is essential for the stability of the double helix, substitution of $\mathrm{Ca}^{2+}$ by $\mathrm{Mg}^{2+}$ was hypothesized to favor the mineralization of DNA. The UV-vis spectra recorded for as prepared, digested and dissolved DNA-MgOx samples are displayed in Figure 5b. Surprisingly, the absorption peak at $266 \mathrm{~nm}$ is very small for the as obtained samples, before and after dissolution (b1 and b3, respectively) and inexistent for the digested ones, before and after dissolution (b2 and b4, respectively). Accordingly, the adsorption 
of DNA onto the mineral surface is lower for $\mathrm{MgOx}$ than for $\mathrm{CaOx}$, whereas the DNA encapsulation was very limited in both cases. These experimental observations are fully consistent with MD simulations on the nucleation of DNA biominerals, in which the formation of DNA $p \cdots \mathrm{Ca}^{2+} \cdots \mathrm{Ox}^{2-}$ and DNA $p \cdots \mathrm{Mg}^{2+} \cdots \mathrm{Ox}^{2-}$ interacting triads were not detected, indicating that $\mathrm{Ox}^{2-}$ anions hinder the mineralization of DNA, independently of the identity of the divalent metallic cation.

Conversely, UV-vis spectra obtained for DNA-HAp complexes shows the presence of both DNA absorbed on the surface and encapsulated inside the particles. Thus, the DNA absorption peak is clearly observed in as prepared complexes, before and after dissolution (c1 and c3, respectively) and in samples dissolved after digestion with the DNAase (c4). Interestingly, the absorbance is much higher for dissolved samples (c3 and c4) than that of as prepared samples (c1 and c2), evidencing the very high tendency of HAp to grow surrounding the DNA molecule that acts as the nucleating template.

It is worth noting that the experimental observations achieved for DNA-CaOx, DNAMgOx and DNA-HAp complexes are fully consistent with the computer simulations discussed above. Thus, MD simulations showed that, although DNA can be adsorbed onto the most stable facets of $\mathrm{CaOx}$ and, especially, HAp, its predominant role as nucleating template only occurs for HAp. On the other hand, $\mathrm{Mg}^{2+}$ ions tend to be located in the grooves of DNA, acting as counterions of the polyphosphate backbone. Nevertheless, $\mathrm{MgOx}$ particles are not appropriated to mineralize the DNA by superficial absorption or encapsulation.

\section{QM calculations}

Interactions between the different species involved in DNA-CaOx complexes were further studied to completely understand the poor affinity of DNA by $\mathrm{CaOx}$ in 
comparison to HAp. For this purpose, QM calculations in vacuum and within the framework of an implicit solvation model were performed on small representative model complexes involving two or three interacting species, which are depicted in Figure 6. The estimated $\Delta \mathrm{G}_{\mathrm{b}}$ and $\Delta \mathrm{G}_{\mathrm{hyd}}$ values, which were calculated as is indicated in the Methods section, are expected to complete the scenario described by classical MD simulations. The $\Delta \mathrm{G}_{\mathrm{b}}$ informs about the strength of the interactions that maintain the species involved in the complex assembled in aqueous solution, while $\Delta \mathrm{G}_{\text {hyd }}$ gives the free energy change associated with the transfer of the complex between vacuum and bulk water. The $\Delta \mathrm{G}_{\mathrm{b}}$ and $\Delta \mathrm{G}_{\text {hyd }}$ values included in Figure 6 completely support the conclusions derived from MD simulations and experimental observations.

First inspection of the $\Delta \mathrm{G}_{\mathrm{b}}$ and $\Delta \mathrm{G}_{\mathrm{hyd}}$ values reveals that the strength of the binding is more exothermic in complexes with $\mathrm{Mg}^{2+}$ than with $\mathrm{Ca}^{2+}$, whereas hydration favors the latter with respect to the former. Careful analysis reveals that when differential energies are considered for the calculated complexes, this behavior can be explained. The $\Delta \mathrm{G}_{\mathrm{b}}$ is more attractive for $\mathrm{Mg}^{2+} \ldots \mathrm{DNA} p$ than for $\mathrm{Ca}^{2+} \ldots \mathrm{DNA} p$ (i.e. $\Delta \Delta \mathrm{G}_{\mathrm{b}}=-32.5$ $\mathrm{kcal} / \mathrm{mol}$ ), indicating that the phosphates from DNA tend to coordinate $\mathrm{Mg}^{2+}$ instead of $\mathrm{Ca}^{2+}$ when both ions are present. The same trend is observed for $\mathrm{Mg}^{2+} \ldots \mathrm{Ox}^{2-}$ and $\mathrm{Ca}^{2+} \ldots \mathrm{Ox}^{2-}$ complexes, the strength of the binding being higher in the former than in the latter (i.e. $\Delta \Delta \mathrm{G}_{\mathrm{b}}=-46.0 \mathrm{kcal} / \mathrm{mol}$ ). However, $\Delta \mathrm{G}_{\mathrm{hyd}}$ indicates the opposite, the solvation being significantly more favored for complexes with $\mathrm{Ca}^{2+}$ than with $\mathrm{Mg}^{2+}$ (i.e. $\Delta \Delta \mathrm{G}_{\text {hyd }}=$ -42.0 and $-49.5 \mathrm{kcal} / \mathrm{mol}$ for complexes with $\mathrm{DNA} p$ and $\mathrm{Ox}^{2-}$, respectively). The balance between $\Delta \Delta \mathrm{G}_{\mathrm{b}}$ and $\Delta \Delta \mathrm{G}_{\mathrm{hyd}}$ values indicates that, in a solution containing all the considered species, $\mathrm{Ox}^{2-}$ preferentially interacts with $\mathrm{Ca}^{2+}$ while DNA phosphate prefers $\mathrm{Mg}^{2+}$ 
Additional calculations on model complexes involving three interacting species provide complete understanding of the in lab experiments described in the previous subsection for $\mathrm{CaOx}$ and $\mathrm{MgOx}$. Thus, the strength of the binding in $\mathrm{Ox}^{2-} \cdots \mathrm{Mg}^{2+} \cdots \mathrm{Ox}^{2-}$ is stronger than in $\mathrm{Ox}^{2-} \cdots \mathrm{Ca}^{2+} \ldots \mathrm{Ox}^{2-}$ by $\Delta \Delta \mathrm{G}_{\mathrm{b}}=-33.4 \mathrm{kcal} / \mathrm{mol}$, while the hydration of the latter is favored with respect to that of the former by $\Delta \Delta \mathrm{G}_{\mathrm{hyd}}=-40.1 \mathrm{kcal} / \mathrm{mol}$. Therefore, the sum of these free energy gaps indicates that $\mathrm{Ox}^{2-}$ anions tend to surround and coordinate with $\mathrm{Ca}^{2+}$ instead of $\mathrm{Mg}^{2+}$. Amazingly, this tendency is much more pronounced for DNAp $\cdots \mathrm{Mg}^{2+} \cdots \mathrm{Ox}^{2-}$ and DNAp$\cdots \mathrm{Ca}^{2+} \cdots \mathrm{Ox}^{2-}$ complexes. Thus, although the binding is favored in the former complex by $\Delta \Delta \mathrm{G}_{\mathrm{b}}=-35.0$, hydration stabilizes the latter by $\Delta \Delta \mathrm{G}_{\mathrm{hyd}}=-60.2 \mathrm{kcal} / \mathrm{mol}$. These and the previous $\Delta \Delta \mathrm{G}_{\mathrm{b}}$ and $\Delta \Delta \mathrm{G}_{\mathrm{hyd}}$ differences indicate that the coordination of an extra $\mathrm{Ox}^{2-}$ with already $\mathrm{Ox}^{2-}-$ bound $\mathrm{Ca}^{2+}$ or $\mathrm{Mg}^{2+}$ instead of DNAp-bound $\mathrm{Mg}^{2+}$ is favored before the precipitation of any of the complexes may happen. In addition, $\mathrm{Ca}^{2+} \ldots \mathrm{Ox}^{2-}$ and $\mathrm{Ox}^{2-} \cdots \mathrm{Ca}^{2+} \ldots \mathrm{Ox}^{2-}$ have much more favorable hydration than their corresponding $\mathrm{Mg}^{2+}$ counterparts. Finally, $\mathrm{Mg}^{2+}$ prefers to coordinate with two $\mathrm{Ox}^{2-}$ rather than with DNAp and $\mathrm{Ox}^{2-}$, which enables $\mathrm{CaOx}$ and $\mathrm{MgOx}$ calcifications to grow DNA-free in the solution as previously confirmed by in the lab tests.

\section{CONCLUSIONS}

In summary, we systematically compared the mineralization of DNA in $\mathrm{CaOx}$ and HAp using a synergistic computational-experimental approach. Being the latter materials traditionally related with transfection of cells with nucleic acids and with the formation of microcalcifications inside of living organisms, the biomedical application of DNA-based biominerals might be further improved by understanding the fundamental interactions associated to adsorption and encapsulation of such 
biomolecule in HAp and $\mathrm{CaOx}$. Using atomistic MD simulations, we studied DNA adsorption and encapsulation in $\mathrm{CaOx}$ and HAp. Although DNA can be adsorbed onto the most stable facet of the two minerals, important differences are found. HAp is able to preserve the DNA double helix because of the complementarity between their phosphate anions through isomorphic planes, while the repulsive interactions between the oxalate anions of $\mathrm{CaOx}$ and the polyphosphate backbone of the biomolecule cause the destabilization of the double helix. Besides, DNA nucleates the growing of HAp when it is immersed in an ionic solution containing $\mathrm{Ca}^{2+}, \mathrm{Mg}^{2+}$ and $\mathrm{PO}_{4}{ }^{3-}$ ions and encapsulates it inside HAp nanopores maintaining the stability of the double helix. The opposite behavior is observed when DNA is immersed in a $\mathrm{Ca}^{2+}, \mathrm{Mg}^{2+}$ and $\mathrm{Ox}^{2-}$ solution and encapsulated in $\mathrm{CaOx}$ pores: the minerals grow separately from DNA and the double helix undergoes severe structural alterations, respectively. These theoretical results have been corroborated experimentally by preparing DNA-HAp, DNA-CaOx and DNA-MgOx complexes. UV-vis spectra show that HAp is much more effective than $\mathrm{CaOx}$ and $\mathrm{MgOx}$ for DNA mineralization in terms of both adsorption and encapsulation. Furthermore, QM calculations on model complexes in aqueous solution show that $\mathrm{Ca}^{2+}$ ions prefer to coordinate with two $\mathrm{Ox}^{2-}$ than form triads involving an $\mathrm{Ox}^{2-}$ and a phosphate group from DNA.

Another fundamental insight obtained in this work is that results described above are independent of the methylation degree of the simulated DNA dodecamers. This is very relevant in the medical context since $\mathrm{CaOx}$ and HAp breast cancer micro-calcifications have been associated with more frequent benign and malign prognosis, respectively. Results derived from this study open a new concept that deserves further research, suggesting that HAp microcalcifications might be involved in the protection and transport of carcinogenic DNA. 


\section{ACKNOWLEDGEMENTS}

Authors acknowledge MINECO-FEDER (RTI2018-098951-B-I00 and RTI2018101827-B-I00), Agència de Gestió d'Ajuts Universitaris i de Recerca (2017SGR359 and 2017SGR373) and B. Braun Surgical, S.A. for financial support. This work is integrated within a wider research project supported by B. Braun Surgical S.A., UPC, ICS and ICFO. Support for the research of C.A. was received through the prize "ICREA Academia" for excellence in research funded by the Generalitat de Catalunya.

\section{REFERENCES}

(1) Tan, L. H.; Xing, H.; Lu, Y. DNA as a Powerful Tool for Morphology Control, Spatial Positioning, and Dynamic Assembly of Nanoparticles. Acc. Chem. Res. 2014, 47, 1881-1890.

(2) Zhou, W.; Saran, R.; Liu, J. Metal Sensing by DNA. Chem. Rev. 2017, 117, $8272-8325$.

(3) Wang, H.; Yang, R.; Yang, L.; Tan, W. Nucleic Acid Conjugated Nanomaterials for Enhanced Molecular Recognition. ACS Nano 2009, 3, 2451-2460.

(4) Giljohann, D. A.; Seferos, D. S.; Daniel, W. L.; Massich, M. D.; Patel, P. C.; Mirkin, C. A. Gold Nanoparticles for Biology and Medicine. Angew. Chem., Int. Ed. 2010, 49, 3280-3294.

(5) Jones, M. R.; Seeman, N. C.; Mirkin, C. A. Programmable Materials and the Nature of the DNA Bond. Science 2015, 347, 1260901.

(6) Song, S.; Qin, Y.; He, Y.; Huang, Q.; Fan, C.; Chen, H.-Y. Functional Nanoprobes for Ultrasensitive Detection of Biomolecules. Chem. Soc. Rev. 2010, 39, 4234-4243. 
(7) Liu, B.; Salgado, S.; Maheshwari, V.; Liu, J. DNA Adsorbed on Graphene and Graphene Oxide: Fundamental Interactions, Desorption and Applications. Curr. Opin. Colloid Interface Sci. 2016, 26, 41-49.

(8) Pautler, R.; Kelly, E. Y.; Huang, P.-J. J.; Cao, J.; Liu, B.; Liu, J. Attaching DNA to Nanoceria: Regulating Oxidase Activity and Fluorescence Quenching. ACS Appl. Mater. Interfaces 2013, 5, 6820-6825.

(9) Narasaraju, T. S. B.; Phebe, D. E. Some Physico-Chemical Aspects of Hydroxylapatite. J. Mater. Sci. 1996, 31, 1-21.

(10) Weiner, S.; Wagner, H. D. THE MATERIAL BONE: Structure-Mechanical Function Relations. Annu. Rev. Mater. Sci. 1998, 28, 271-298.

(11) Fratzl, P.; Gupta, H. S.; Paschalis, E. P.; Roschger, P. Structure and Mechanical Quality of the Collagen-Mineral Nano-Composite in Bone. J. Mater.Chem. 2004, 14, $2115-2123$.

(12) Uskoković, V.; Uskoković, D. P. Nanosized Hydroxyapatite andOther Calcium Phosphates: Chemistry of Formation and Application as Drug and Gene Delivery Agents. J. Biomed. Mater. Res., Part B 2011, 96B, 152-191.

(13) Kozlova, D.; Chernousova, S.; Knuschke, T.; Buer, J.; Westendorf, A. M.; Epple, M. Cell Targeting by Antibody-Functionalized Calcium Phosphate Nanoparticles. $J$. Mater. Chem. 2012, 22, 396-404.

(14) Olton, D.; Li, J.; Wilson, M.E.; Rogers, T.; Close, J.; Huang, L.; Kumta, P.N.;

Sfeir, C. Nanostructured Calcium Phosphates (NanoCaPs) for Non-Viral Gene Delivery: Influence of the Synthesis Parameters on Transfection Efficiency. Biomaterials 2007, 28, 1267-1279. 
(15) Wan, Y.; Wu, C.; Zuo, G.; Xiong, G.; Jin, J.; Guo, R.; Wang, Z.; Luo, H.

Controlled Template Synthesis of Lamellar Hydroxyapatite Nanoplates as a Potential Carrier for Gene Delivery. Mater. Chem. Phys. 2015, 156, 238-246.

(16) Andrews-Pfannkoch, C.; Fadrosh, D. W.; Thorpe, J.; Williamson, S. J.

Hydroxyapatite-Mediated Separation of Double-Stranded DNA, Single-Stranded DNA, and RNA Genomes from Natural Viral Assemblages. Appl. Environ. Microb. 2010, 76, 5039-5045.

(17) Baker, R.; Rogers, K. D.; Shepherd, N.; Stone, N. New Relationships between Breast Microcalcifications and Cancer. British J. Cancer 2010, 103, 1034-1039.

(18) Haka, A. S.; Shafer-Peltier, K. E.; Fitzmaurice, M.; Crowe, J.; Dasari, R. R.; Feld, M. S. Diagnosing Breast Cancer by Using Raman Spectroscopy. Proc. Natl. Acad. Sci. 2005, 102, 12371-12376.

(19) Haka, A. S.; Shafer-Peltier, K. E.; Fitzmaurice, M.; Crowe, J.; Dasari, R. R.; Feld, M. S. Identifying Microcalcifications in Benign and Malignant Breast Lesions by Probing Differences in Their Chemical Composition using Raman Spectroscopy. Cancer Res. 2002, 62, 5375-5380.

(20) Tse, G. M.; Tan, P.-H. Cheung, H. S.; Chu, W. C.; Lam, W. W. Intermediate to Highly Suspicious Calcification in Breast Lesions: A Radio-Pathologic Correlation. Breast Cancer Res. Treat. 2008, 110,1-7.

(21) Frappart, L.; Boudeulle, M.; Boumendil, J.; Lin, H. C.; Martinon, I.; Palayer, C.; Mallet-Guy, Y.; Raudrant, D.; Bremond, A.; Rochet, Y. Structure and Composition of Microcalcifications in Benign and Malignant Lesions of the Breast: Study by Light Microscopy, Transmission and Scanning Electron Microscopy, Microprobe Analysis, and X-Ray Diffraction. Hum. Pathol. 1984, 15, 880-889. 
(22) Cox, R. F.; Hernandez-Santana, A.; Ramdass, S.; McMahon, G.; Harmey, J. H.; Morgan, M. P. Microcalcifications in Breast Cancer: Novel Insights into the Molecular Mechanism and Functional Consequence of Mammary Mineralisation. Br. J. Cancer 2012, 106, 3, 525-537.

(23) del Valle, L. J.; Bertran, O.; Chaves, G.; Revilla-López, G.; Rivas, M.; Casas, M. T.; Casanovas, J.; Turon, P.; Puiggalí, J.; Alemán, C. DNA Adsorbed on Hydroxyapatite Surfaces. J. Mater. Chem. 2014, 2, 6953-6966.

(24) Rivas, M.; Casanovas, J.; del Valle, L. J.; Bertran, O.; Revilla-López, G.; Turon, P.; Puiggalí, J.; Alemán, C. An Experimental-Computer Modeling Study of Inorganic Phosphates Surface Adsorption on Hydroxyapatite Particles. Dalton Trans. 2015, 44, 9980-9991.

(25) Revilla-López, G.; Casanovas, J.; Bertran, O.; Turon, P.; Puiggalí, J.; Alemán, C. Modeling Biominerals Formed by Apatites and DNA. Biointerphases 2013, 8, 10. (26) Takeshita, T.; Matsuura, Y.; Arakawa, S.; Okamoto, M. Biomineralization of Hydroxyapatite on DNA Molecules in SBF: Morphological Features and Computer Simulation. Langmuir 2013, 29, 11975-11981.

(27) Vasconcellos, K. B.; McHugh, S. M.; Dapsis, K. J.; Petty, A. R.; Gerdon, A. E. Biomimetic Nanoparticles with Polynucleotide and PEG Mixed-Nonolayers Enhance Calcium Phosphate Mineralization. J. Nanopart. Res., 2013, 15, 1942.

(28) Bertran, O.; del Valle, L. J.; Revilla-López, G.; Chaves, G.; Cardus, L.; Casas, M. T.; Casanovas, J.; Turon, P.; Puiggalí, J.; Alemán, C. Mineralization of DNA into Nanoparticles of Hydroxyapatite. Dalton Trans. 2014, 43, 317-327.

(29) Klesing, J.; Chernousova, S.; Epple, M. Freeze-Dried Cationic Calcium Phosphate Nanorods as Versatile Carriers of Nucleic Acids (DNA, siRNA). J. Mater. Chem. 2012, 22, 199-204 
(30) Wu, G. J.; Zhou, L. Z.; Wang, K. W.; Chen, F.; Sun, Y.; Duan, Y. R.; Zhu, Y. J.;

Gu, H. C. Hydroxylapatite Nanorods: An Efficient and Promising Carrier for Gene Transfection. J. Colloid Interface Sci. 2010, 345, 427-432.

(31) Zhu, S. H.; Huang, B. Y.; Zhou, K. C.; Huang, S. P.; Liu, F.; Li, Y. M.; Xue, Z. G.; Long, Z. G. Hydroxyapatite Nanoparticles As a Novel Gene Carrier. J. Nanopart. Res. 2004, 6, 307-311.

(32) Bertran, O.; del Valle, L. J.; Revilla-López, G. Rivas, M.; Chaves, M.; Casas, M. T.; Casanovas, J.; Turon, P.; Puiggalí, J.; Alemán, C.Synergistic Approach to Elucidate the Incorporation of Magnesium Ions into Hydroxyapatite. Chem. Eur. J. 2015, 21, $2537-2546$.

(33) Betran, O.; Revilla-López, G.; Casanovas, J.; del Valle, L. J.; Turon, P.; Puiggalí, J.; Alemán, C. Dissolving Hydroxyolite: A DNA Molecule into Its Hydroxyapatite Mold. Chem. Eur. J. 2016, 22, 6631-6636.

(34) Phillips, J. C.; Braun, R.; Wang, W.; Gumbart, J.; Tajkhorshid, E.; Villa, E.; Chipot, C.; Skeel, R. D.; Kalé, L.; Schulten, K. Scalable Molecular Dynamics with NAMD. J. Comput. Chem. 2005, 26, 1781-1802.

(35) Fleischer, T.; Tekpli, X.; Mathelier, A.; Wang, S.; Nebdal, D.; Dhakal, H. P.; Kleivi, K.; Sahlberg, K. K.; Schlichting, E; Oslo Breast Cancer Research Consortium (OSBREAC); Børresen-Dale, A. L.; Borgen, E.; Naume, B.; Eskeland, R.; Frigessi, A.; Tost, J.; Hurtado, A.; Kristensen, V. N. DNA Methylation at Enhancers Identifies Distinct Breast Cancer Lineages. Nat. Commun. 2017, 8, 1379.

(36) Si, X.; Zhao, Y.; Yang, C.; Zhang, S.; Zhang, X. DNA Methylation as a Potential Diagnosis Indicator for Rapid Discrimination of Rare Cancer Cells and Normal Cells. Sci. Rep. 2015, 5, 11882. 
(37) Widschwendter, M.; Jones, P. A. DNA Methylation and Breast Carcinogenesis. Oncogene 2002, 21, 5462-5482.

(38) Mathe, A.; Wong-Brown, M.; Locke, W. J.; Stirzaker, C.; Braye, S. G.; Forbes, J. F.; Clark, S. J.; Avery-Kiejda, K. A.; Scott, R. J. DNA Methylation Profile of Triple Negative Breast Cancer-Specific Genes Comparing Lymph Node Positive Patients to Lymph Node Negative Patients. Sci. Rep. 2016, 6, 33435.

(39) Dammann, R.; Yang, G.; Pfeifer, G. P. Hypermethylation of the cpG Island of Ras Association Domain Family 1A (RASSF1A), a Putative Tumor Suppressor Gene from the 3p21.3 Locus, Occurs in a Large Percentage of Human Breast Cancers. Cancer Res. 2001, 61, 3105-3109.

(40) Gueroult, M.; Boittin, O.; Mauffret, O.; Etchebest, C.; Hartmann, B. Charge Neutralization was Performed with the Addition of $\mathrm{Na}^{+}$Counterions. PLoS One 2012, 7, e41704.

(41) Duan, Y.; Wu, C.; Chowdhury, S.; Lee, M. C.; Xiong, G.; Zhang, W.; Yang, R.;

Cieplak, P.; Luo, R.; Lee, T.; Caldwell, J.; Wang, J.; Kollman, P. A. Point-Charge Force Field for Molecular Mechanics Simulations of Proteins Based on Condensed-Phase Quantum Mechanical Calculations. J. Comput. Chem. 2003, 24, 1999-2012.

(42) Bradbrook, G. M.; Gleichmann, T.; Harrop, S. J.; Habash, J.; Raftery, J.; Kalb, J.; Yariv J.; Hillier I. H.; Helliwell, J. R. X-Ray and Molecular Dynamics Studies of Concanavalin-A Glucoside and Mannoside Complexes. Relating Structure to Thermodynamics of Binding. J. Chem. Soc., Faraday Trans. 1998, 94, 1603-1611. (43) Allnér, O.; Nilsson, L.; Villa, A. Magnesium Ion-Water Coordination and Exchange in Biomolecular Simulations. J. Chem. Theor. Comput. 2012, 8, 1493-1502. 
(44) Jorgensen, W. L.; Chandrasekhar, J.; Madura, J. D.; Impey, R. W.; Klein, M. L. Comparison of Simple Potential Functions for Simulating Liquid Water. J. Chem. Phys. 1983, 79, 926-935.

(45) Wang, J.; Wolf, R. M.; Caldwell, J. W.; Kollman, P. A.; Case, D. A. Development and Testing of a General Amber Force Field. J. Comput. Chem. 2004, 25, 1157-1174. (46) Bayly, C. I.; Cieplak, P.; Cornell, W.; Kollman, P. A. A Well-Behaved Electrostatic Potential Based Method Using Charge Restraints for Deriving Atomic Charges: The RESP Model. J. Phys. Chem. 1993, 97, 10269v10280.

(47) Berendsen, H. J.; Postma, J. V.; van Gunsteren, W. F.; DiNola, A. R. H. J.; Haak, J. R. Molecular Dynamics with Coupling to an External Bath. J. Chem. Phys. 1984, 81, 3684-3690.

(48) Darden, T.; York, D.; Pedersen, L. Particle Mesh Ewald: An N·log (N) Method for Ewald sums in Large Systems. J. Chem. Phys. 1993, 98, 10089-10092

(49) Ryckaert, J. P.; Ciccotti, G.; \& Berendsen, H. J. Numerical Integration of the Cartesian Equations of Motion of a System with Constraints: Molecular Dynamics of $n$ Alkanes. J. Comput. Phys. 1977, 23, 327-341.

(50) Stork, L.; Muller, P.; Dronskowski, R.; Ortlepp, J. R. Z. Kristallogr. 2005, 220, 201-205.

(51) Daudon, M.; Bazin, D.; André, G.; Jungers, P.; Cousson, A.; Chevallier, P.; Veéron, E.; Matzen, G. Examination of Whewellite Kidney Stones by Scanning Electron Microscopy and Powder Neutron Diffraction Techniques. J. Appl. Cryst. 2009, $42,109-115$.

(52) M Frisch, M. J.; Trucks, G. W.; Schlegel, H. B.; Scuseria, G. E.; Robb, M. A.; Cheeseman, J. R.; Scalmani, G.; Barone, V.; Mennucci, B.; Petersson, G. A.; Nakatsuji, H.; Caricato, M.; Li, X.; Hratchian, H. P.; Izmaylov, A. F.; Bloino, J.; Zheng, G.; 
Sonnenberg, J. L.; Hada, M.; Ehara, M.; Toyota, K.; Fukuda, R.; Hasegawa, J.; Ishida, M.; Nakajima, T.; Honda, Y.; Kitao, O.; Nakai, H.; Vreven, T.; J. A. Montgomery Jr.; Peralta, J. E.; Ogliaro, F.; Bearpark, M.; Heyd, J. J.; Brothers, E.; Kudin, K. N.;

Staroverov, V. N.; Kobayashi, R.; Normand, J.; Raghavachari, K.; Rendell, A.; Burant, J. C.; Iyengar, S. S.; Tomasi, J.; Cossi, M.; Rega, N.; Millam, J. M.; Klene, M.; Knox, J. E.; Cross, J. B.; Bakken, V.; Adamo, C.; Jaramillo, J.; Gomperts, R.; Stratmann, R. E.; Yazyev, O.; Austin, A. J.; Cammi, R.; Pomelli, C.; Ochterski, J. W.; Martin, R. L.; Morokuma, K.; Zakrzewski, V. G.; Voth, G. A.; Salvador, P.; Dannenberg, J. J.; Dapprich, S.; Daniels, A. D.; Farkas, Ö.; Foresman, J. B.; Ortiz, J. V.; Cioslowski, J.; Fox, D. J. Gaussian 09, Revision A.1. Gaussian, Inc.: Wallingford CT, 2009.

(53) Becke, A. D. Density-Functional Thermochemistry. III. The Role of Exact Exchange. J. Chem. Phys. 1993, 98, 5648-5652.

(54) Lee, C.; Yang, W.; Parr, R. G. Development of the Colle-Salvetti CorrelationEnergy Formula into a Functional of the Electron Density. Phys. Rev. B: Condens. Matter. 1988, 37, 785-789.

(55) Marenich, A. V.; Cramer, C. J.; Truhlar, D. G. Universal Solvation Model Based on Solute Electron Density and on a Continuum Model of the Solvent Defined by the Bulk Dielectric Constant and Atomic Surface Tensions. J. Phys. Chem. B 2009, 113, 6378-6396.

(56) Mkhonto, D.; de Leeuw, N. H. A Computer Modelling Study of the Effect of Water on the Surface Structure and Morphology of fFluorapatite: Introducing a $\mathrm{Ca}_{10}\left(\mathrm{PO}_{4}\right)_{6} \mathrm{~F}_{2}$ Potential Model. J. Mater. Chem. 2002, 12, 2633-2642.

(57) Di Tommaso, D.; Hernández, S. E. R.; Du, Z.; de Leeuw, N. H. Density Functional Theory and Interatomic Potential Study of Structural, Mechanical and Surface Properties of Calcium Oxalate Materials. RSC Adv. 2012, 2, 4664-4674. 
(58) Almora-Barrios, N.; Austen, K. F.; de Leeuw, N. H. Density Functional Theory Study of the Binding of Glycine, Proline, and Hydroxyproline to the Hydroxyapatite (0001) and (0110) Surfaces. Langmuir 2009, 25,5018-5025.

(59) Filgueiras, M. R. T.; Mkhonto, D.; de Leeuw, N. H. Computer Simulations of the Adsorption of Citric Acid at Hydroxyapatite Surfaces. J. Cryst. Growth 2006, 294, 6068.

(60) de Leeuw, N. H.; Rabone, J. A. L. Molecular Dynamics Simulations of the Interaction of Citric Acid with the Hydroxyapatite (0001) and $\left(011^{-} 0\right)$ Surfaces in an Aqueous Environment. CrystEngComm 2007, 9, 1178-1186.

(61) Sandersius, S.; Rez, P. Morphology of Crystals in Calcium Oxalate Monohydrate Kidney Stones. Urol. Res. 2007, 35, 287-293.

(62) Sheng, X. X.; Jung, T. S.; Wesson, J. A.; Ward, M. D. Adhesion at Calcium Oxalate Crystal Surfaces and the Effect of Urinary Constituents. Proc. Natl. Acad. Sci. 2005, 102, 267-272. 


\section{CAPTIONS TO FIGURES}

Figure 1. Axial and equatorial perspectives of the starting models used to represent the DD double helix embedded in $\mathrm{HAp}$ and $\mathrm{CaOx}$ nanopores.

Figure 2. Comparison of DNA adsorption on HAp and monohydrated $\mathrm{CaOx}$. Temporal evolution of the RMSD with respect to the canonical B-DNA double helix for (a) R1A (5'-CG $\left.{ }^{4} \mathrm{GTCG}^{5} \mathrm{CCG}^{6} \mathrm{TCG}^{7}-3^{\prime}\right)$ and (b) DD (5'-CGCGAATTCGCG-3') adsorbed onto the (001) HAp and (100) CaOx facets. The RMSD obtained for the DNA in aqueous solution has been included for comparison. Axial view of the R1A dodecamer adsorbed onto (c) the (001) surface of HAp and (d) the (100) surface of monohydrated $\mathrm{CaOx}$. Oversized black balls highlight the position of carbon of methyl groups in the methylated DNA. For each system, the axial and equatorial views of the canonical double helix (in black) and the R1A double helix adsorbed onto the HAp or $\mathrm{CaOx}$ surface (in red) are compared at the bottom.

Figure 3. (a) RDFs extracted from the MD simulation of the solution containing R1A, water, $\mathrm{Mg}^{2+}, \mathrm{Ca}^{2+}$ and $\mathrm{Ox}^{2-}$. DNAp refers to the DNA phosphate backbone. (b) Superposed snapshot extracted from the simulations with $\mathrm{Ox}^{2-}$ (red box) and $\mathrm{PO}_{4}{ }^{3-}$ (blue ellipsoid) ions. (c) RDFs extracted from the MD simulation of the solution containing $\mathrm{R} 1 \mathrm{~A}$, water, $\mathrm{Mg}^{2+}, \mathrm{Ca}^{2+}$ and $\mathrm{PO}_{4}{ }^{3-}$. In order to ensure that $\mathrm{R} 1 \mathrm{~A} \cdots$ ion and ion $\cdots$ ion interactions had enough time for their formation (if possible), RDFs were calculated in all cases considering only the last 50 ns of productive simulations.

Figure 4. Axial perspective of the R1A and DD double helix embedded in HAp and $\mathrm{CaOx}$ nanopores after relaxation through energy minimization and $\mathrm{MD}$. The double helix is also displayed without mineral to show the different degree of distortion induced by the minerals. 
Figure 5. UV-vis absorption spectra of the (a) DNA-CaOx, (b) DNA-MgOx and (c) DNA-HAp complexes. Spectra of: as prepared samples (\#1, blue solid lines); samples digested with DNAase to eliminate DNA adsorbed on the surface (\#2, red solid lines); dissolved as prepared samples (\#3, blue dashed lines); and dissolved digested samples (\#4, red dashed lines), where \# refers to $\mathrm{a}, \mathrm{b}$ or $\mathrm{c}$.

Figure 6. Quantum mechanics calculated binding free energy in aqueous solution $\left(\Delta \mathrm{G}_{\mathrm{b}} ; \mathrm{kcal} / \mathrm{mol}\right)$ and hydration free energy $\left(\Delta \mathrm{G}_{\mathrm{hyd}} ; \mathrm{kcal} / \mathrm{mol}\right)$ for different complexes including either $\mathrm{Ca}^{2+}$ or $\mathrm{Mg}^{2+}$, oxalate $\left(\mathrm{Ox}^{2-}\right)$ and DNA phosphates ( $p$ DNA): black color letters stands for $\mathrm{Ca}^{2+}$ whereas red color ones for $\mathrm{Mg}^{2+}$. Calculations were performed within the SMD-B3LYP/6-311G++(2d,2p) framework. 


\section{HAp / DD CaOx / DD}

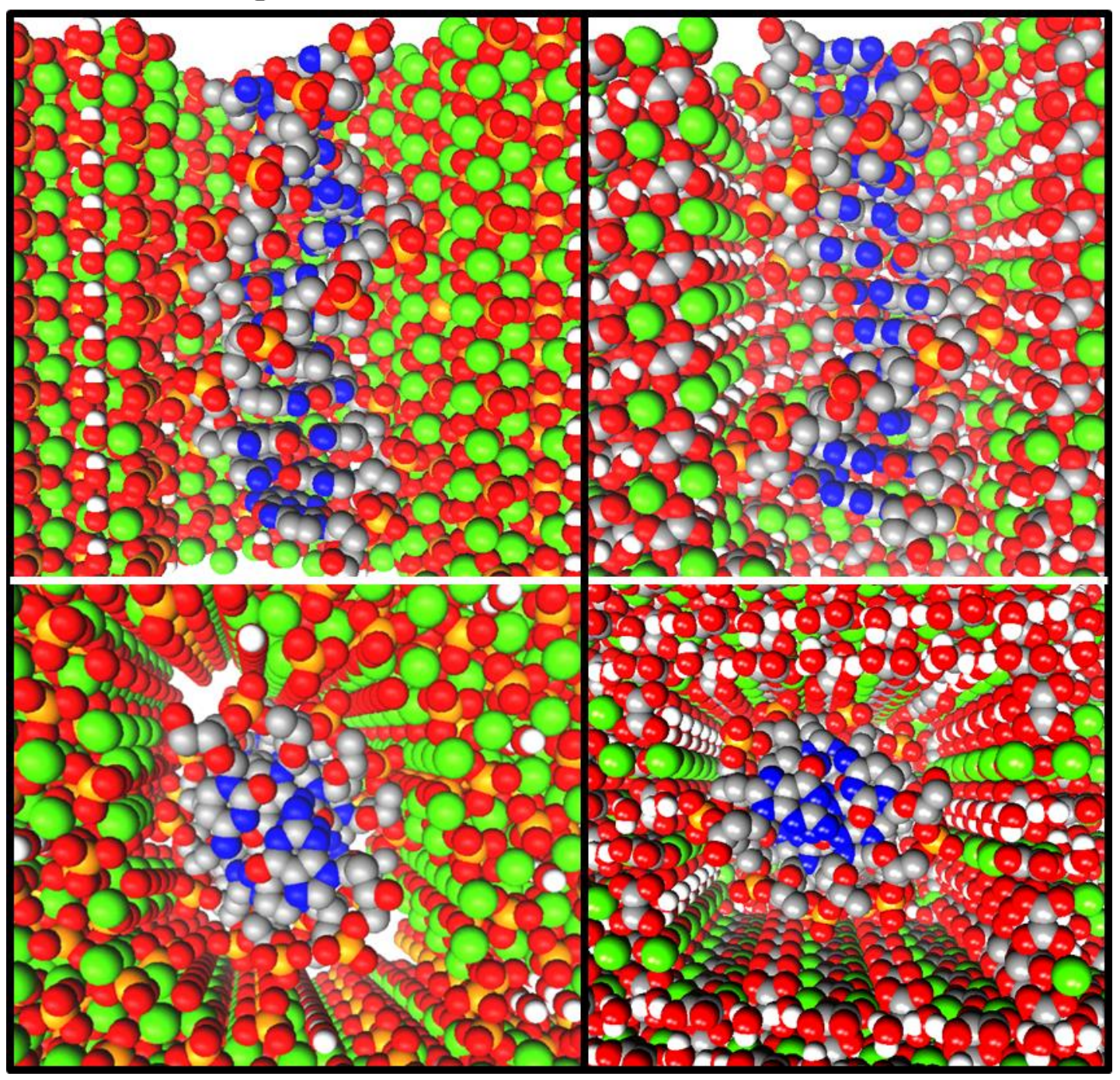

Figure 1 
(a)

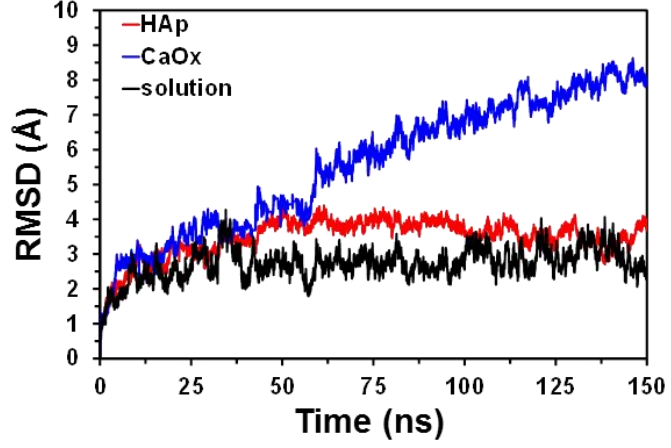

(b)

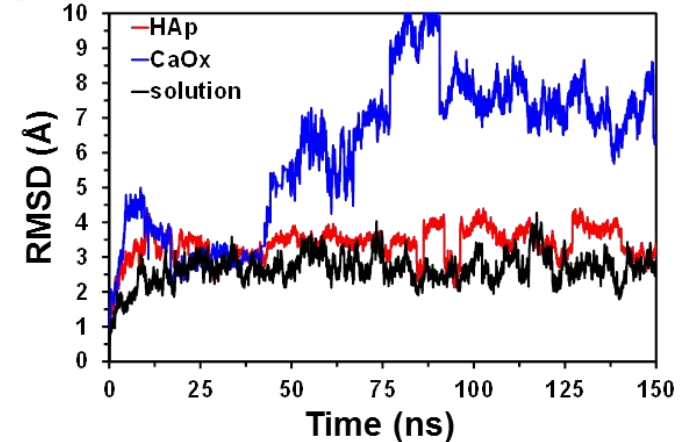

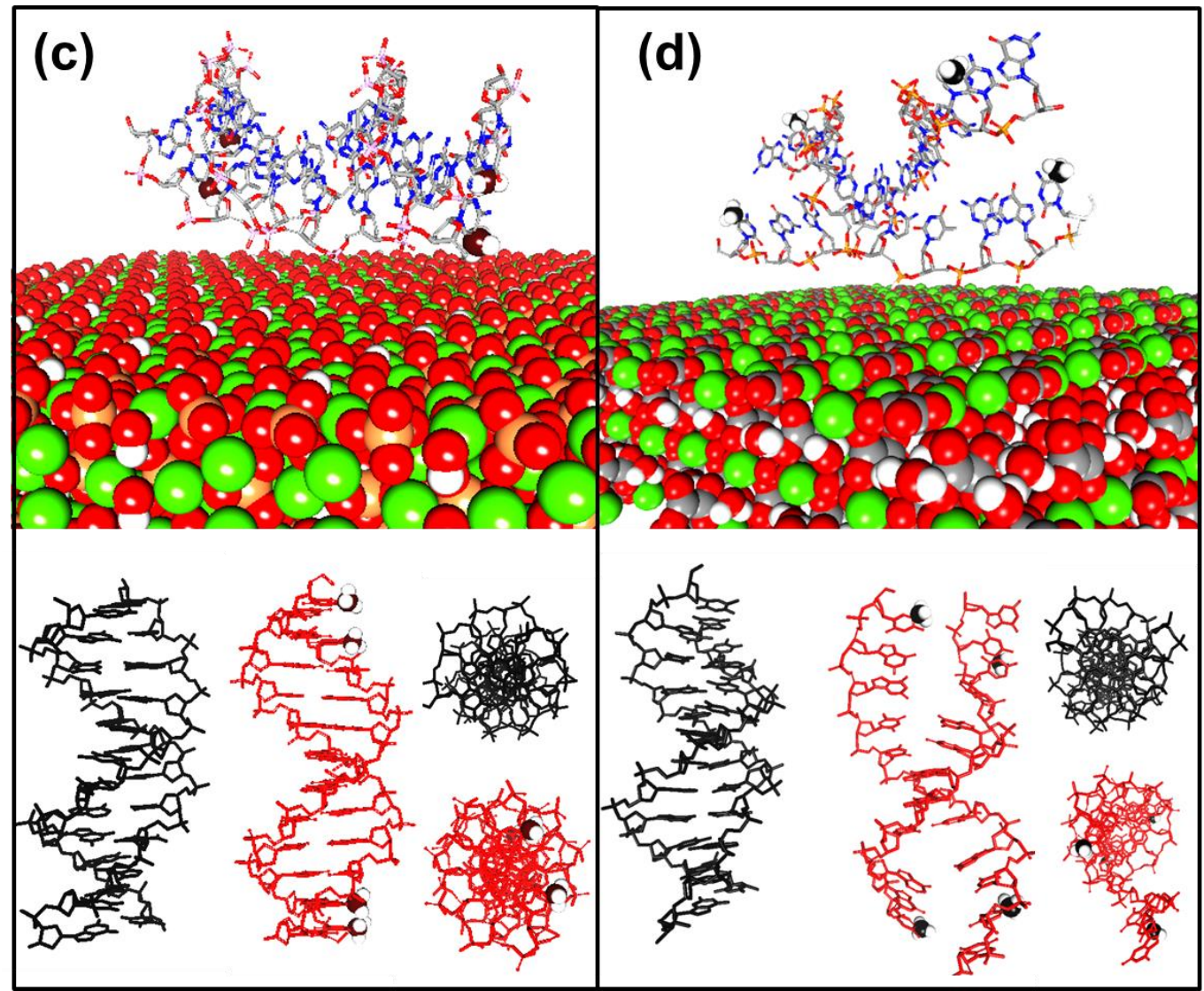

Figure 2 
(a)

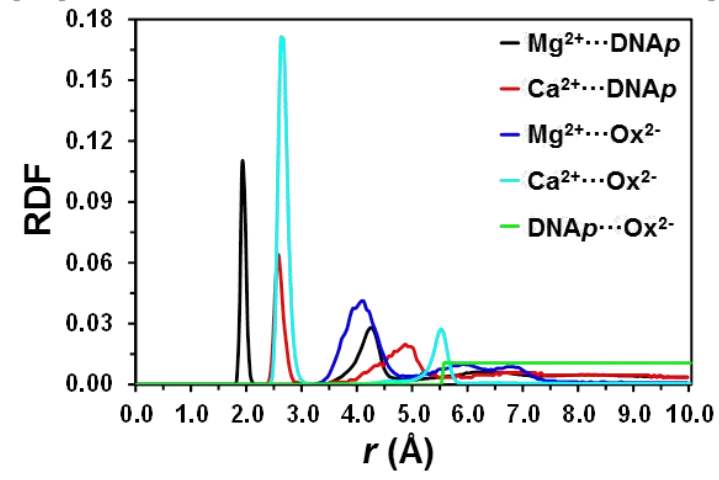

(c)

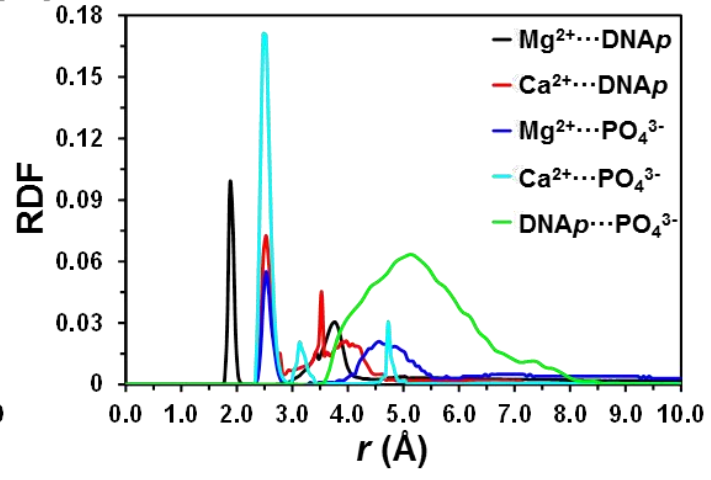

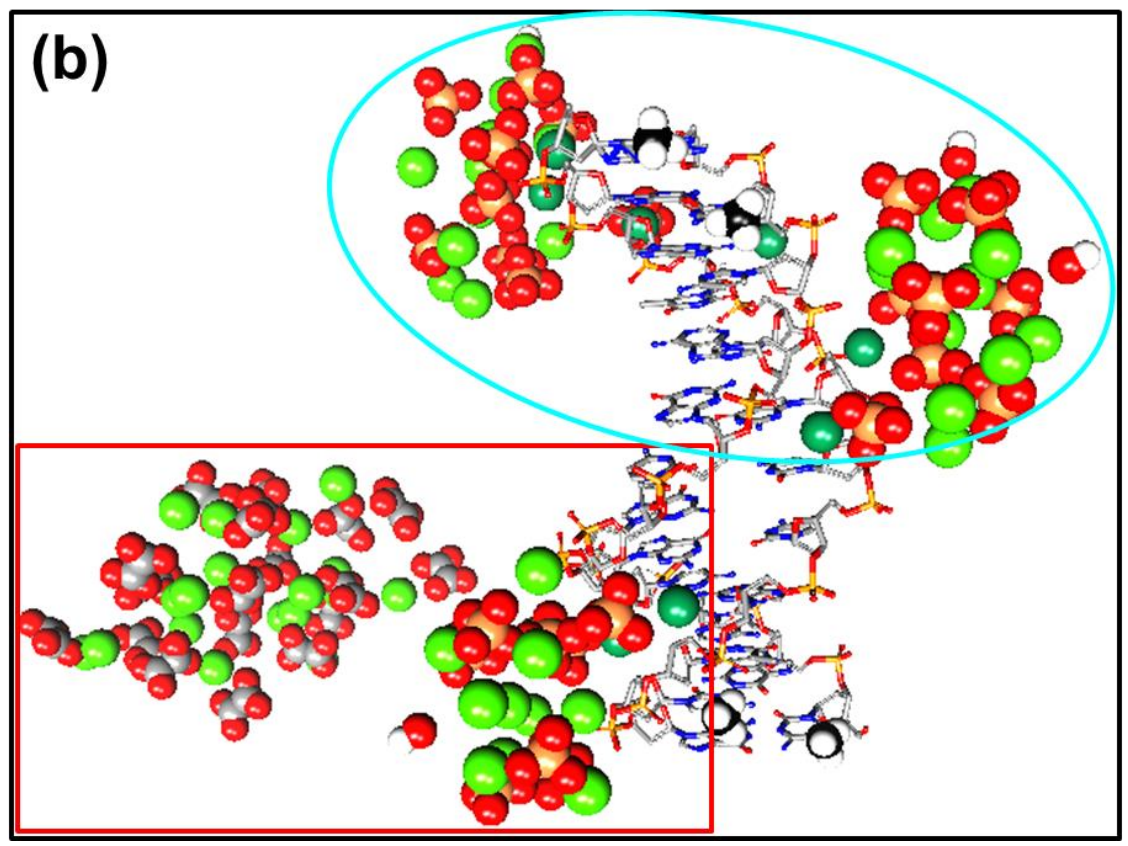

Figure 3 


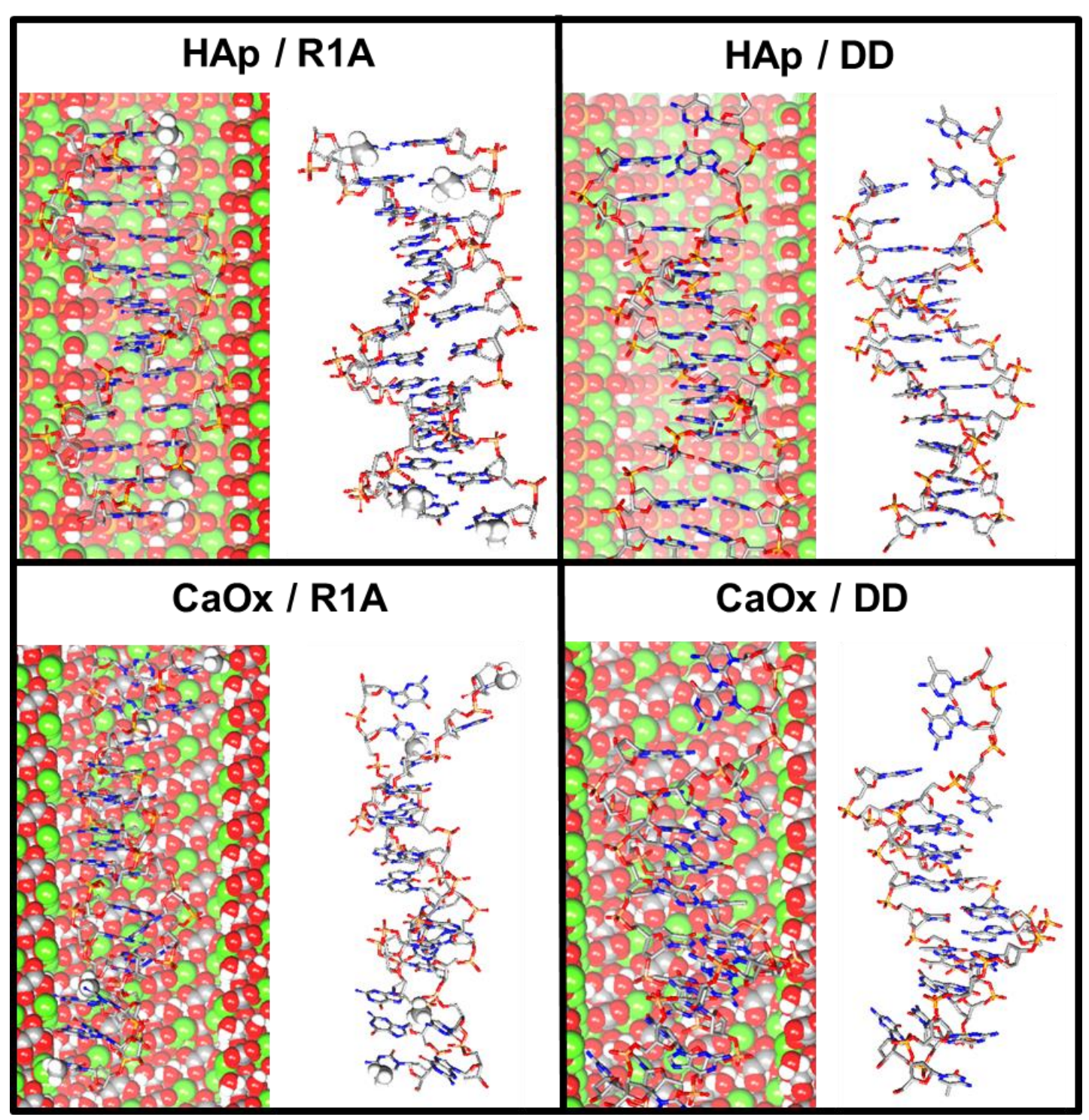

Figure 4 

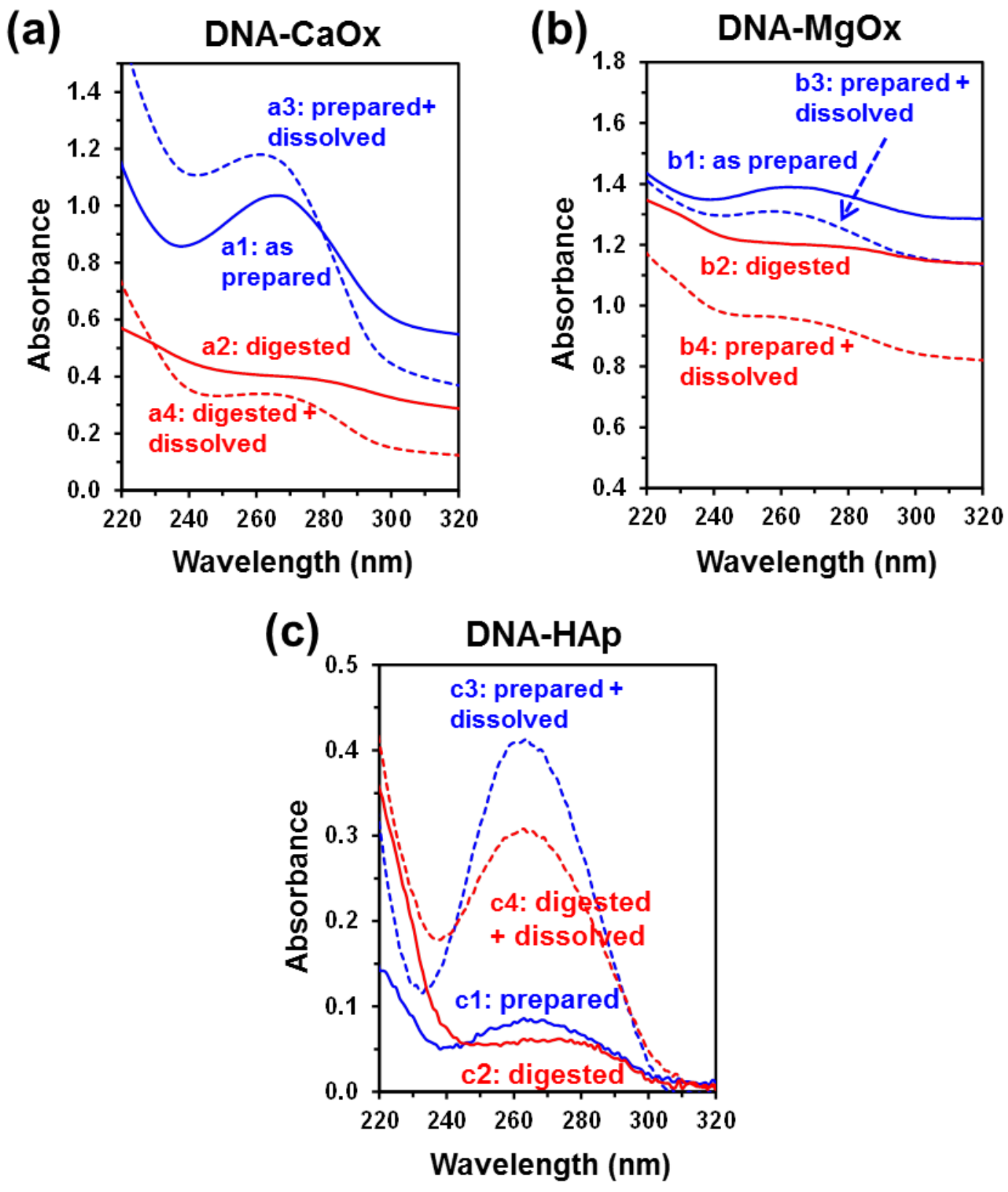

Figure 5 
DNAp $\cdots \mathrm{Ca}^{2+\cdots O \mathrm{x}^{2-}}$
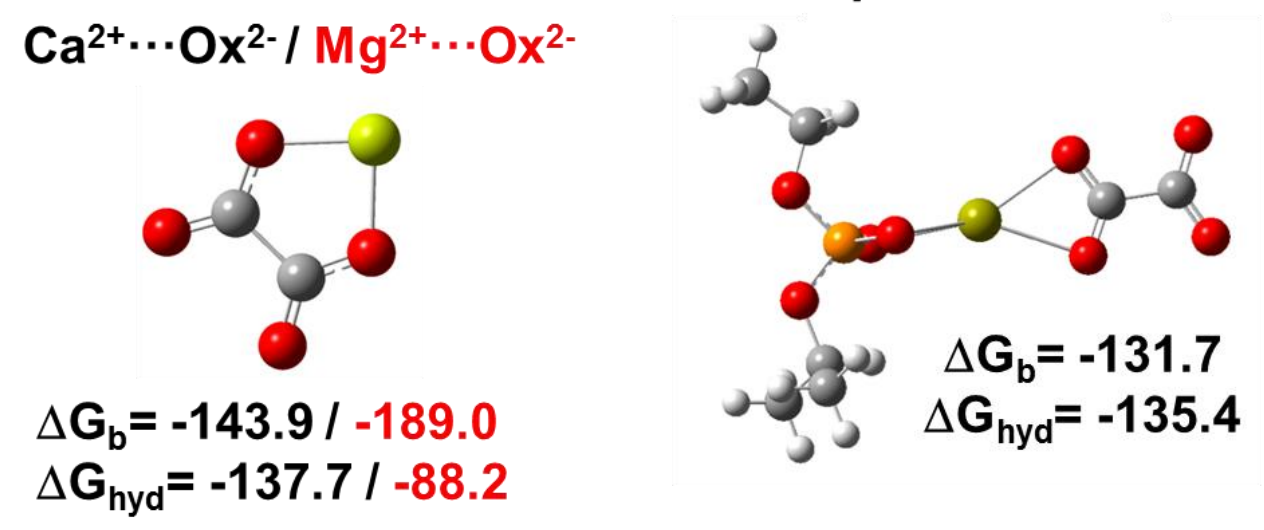

DNAp $\cdots \mathrm{Ca}^{2+} /$ DNAp $\cdots \mathrm{Mg}^{2+}$

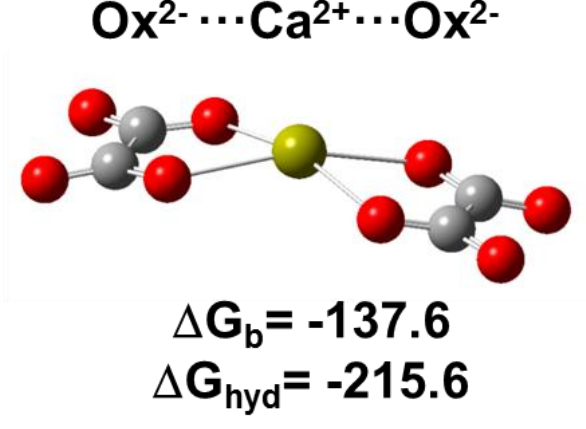

DNAp $\cdots \mathrm{Mg}^{2+\ldots O \mathrm{X}^{2-}}$

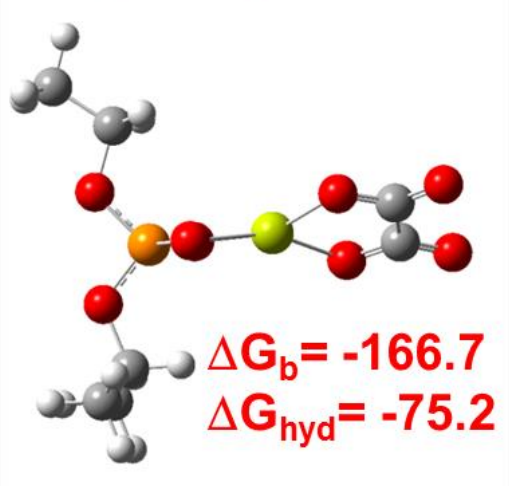

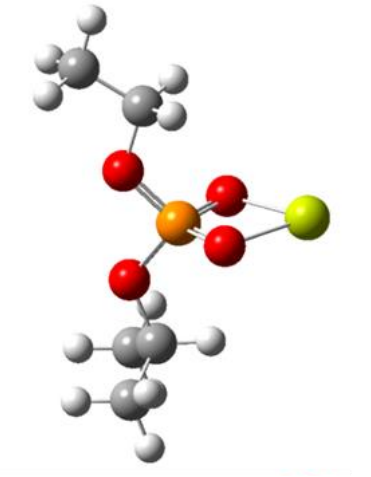

$$
\Delta \mathbf{G}_{\mathrm{b}}=-2.9 /-35.4
$$

$\Delta \mathbf{G}_{\text {hyd }}=-158.1 /-116.1$

$O x^{2-\cdots} \mathrm{Mg}^{2+\ldots O O x^{2-}}$

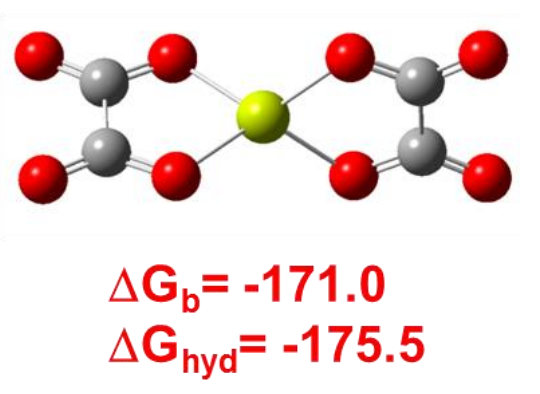

Figure 6 


\section{TOC}

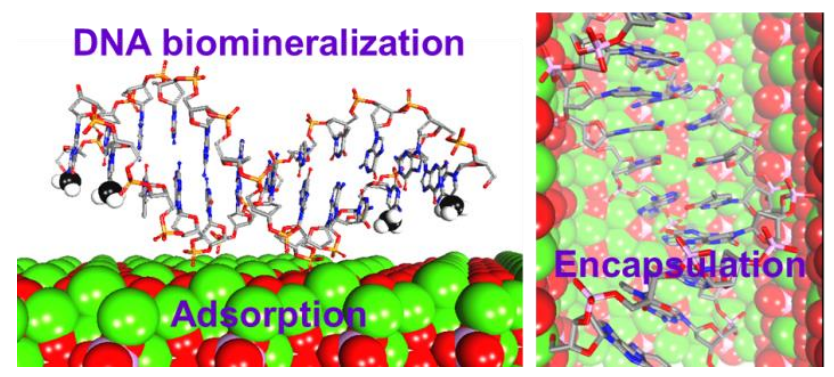

